\title{
Impact of Interspousal Violence and Maternal Deprivation on a Child's Mental and Physical Health: A Case Report
}

\section{Onyiriuka AN ${ }^{1}$}

${ }^{1}$ Dr. Alphonsus N. Onyiriuka, Department of Child health, University of Benin Teaching Hospital, Pmb 1111, Benin City, Nigeria.

Address for correspondence: Dr. Alphonsus N. Onyiriuka, E-mail: alpndiony@yahoo.com

\begin{abstract}
This paper presents a case of an emotionally deprived child with some evidence of child neglect resulting from separation of parents (maternal deprivation). It also further confirms the long recognized fact that the most successful treatment of growth failure and weight loss due to psychosocial deprivation is restoration of a normal social environment. In particular, it highlights the need for a high index of suspicion and awareness on the part of medical personnel with regard to emotional disorders in children.
\end{abstract}

Key words: Maternal deprivation, child neglect, psychological deprivation.

\section{Introduction}

$\mathrm{T}^{\mathrm{n}}$ he World Health Organisation defines violence ${ }^{1}$ as: "The intentional use of physical force or power, threatened or actual, against oneself, another person or against a group or community, which either results in or has a high likelihood of resulting in injury, death, psychological harm, maldevelopment or deprivation."

Violence by intimate partners is an important public health issue, occurring in all countries, all cultures and at every social strata ${ }^{2,3}$. Often, the children in these households witness these episodes of marital violence. For example, in two separate studies, one in Ireland ${ }^{4}$ and the other in Mexico ${ }^{5}, 64 \%$ and $50 \%$ respectively of the abused women reported that their children witnessed the violence. It is estimated that worldwide 3 to 10 million children per year witness intimate partner violence $^{6}$. Witnessing violence is detrimental to children in that it threatens their healthy development by affecting them psychologically and behaviourally ${ }^{6}$. In a review of 48 population-based surveys from around the world, it was reported that $10-69 \%$ of women have experienced physical assault at the hands of an intimate male partner at some point in their lives ${ }^{7}$.

In adults, reactions to social-situational stresses vary greatly. This is even more so with children. Research reports indicate that children who witness marital violence are at a higher risk for a whole range of emotional and behavioural problems including anxiety, depression, poor school performance, low selfesteem, disobedience, nightmares and physical health complaint $^{8-10}$. The separation of a child's parents has a profound effect on them. As a result of separation of parents, children may present with ${ }^{11,12}$ :

1. Behavioural problems such as temper tantrum with destructive behaviour as the child subconsciously blames a parent for the separation.

2. Reduced academic performance.

3. Non-organic problems such as abdominal pain, vomiting and headaches.

4. Child abuse and neglect following the introduction of an unsuitable partner into the household.

The impact of emotional deprivation depends on the age and stage of development of the child, quality of relationship with the absent person, nature (length and completeness) of the separation, experiences during the period of separation and the attitude of parents when child is returned to them ${ }^{13}$. Emotional deprivation may result in listlessness, emaciation, quietness, loss of appetite, general apathy and psychosomatic illness ${ }^{13}$. A high index of suspicious and awareness are required by medical personnel, otherwise the underlying emotional 
basis will be missed and the child evaluated superficially for organic cause of the symptoms.

This paper presents a case seen on $25^{\text {th }}$ October 2008 at St. Philomena Catholic Hospital (SPCH), Benin City, Nigeria which illustrates some of the ill-effects of interspousal violence and maternal deprivation on a Nigerian child's mental health. It also highlights the need for high index of suspicion and awareness on the part of medical personnel with regard to emotional disorders.

\section{The Case}

B.M. is a five year old boy who is the elder of two children and who is closely attached to his mother (a 28year old school-certificate holder and a full-time house wife). He was a bright and cheerful child who was in the custody of his mother following separation of his parents when he was two years old. The relationship between his father and mother became strained when his father decided he will marry a second wife. B.M.'s mother did not approve of her husband's plan. This disagreement resulted in B.M.'s father becoming increasingly aggressive towards his wife. Eventually, it culminated in several episodes of physical abuse of B.M.'s mother, especially each time the would-be second wife visited. Despite this protest by B.M.'s mother, her husband went ahead and married a second wife. B.M.'s mother had to leave the household with her two children and returned to her parents in Lokoja. B.M.'s father, 35-year old university graduate with a lucrative job in a big company refused to provide for the up-keep of his two children. B.M. lived with his mother in Lokoja for two years and nine months but when his mother could no longer cope, she brought B.M. to his father in Benin City and left for Lokoja where she then resided. For the first three days, B.M. had good appetite and ate voraciously. Thereafter he lost appetite and ate very little and slowly. B.M.'s class teacher reported that he does not play with classmates at school and also refused to write or participate in class activities. At home, B.M. was unusually quiet especially when step-mother was around. Also he does not play with age-mates in the neighbourhood. B.M. not only did not eat his food, he also vomits into it. This was associated with weight loss. B.M.'s stepmother, on the instruction of her husband, sought for medical help. One important feature of this case is that two previous medical consultations have been made in another hospital. The first with a Non-specialist General Medical Practitioner and the second, a month later, with a Consultant Paediatrician. Both doctors made a diagnosis of "Helminthiasis" (step-mother brought the case records with her). The first doctor prescribed albendazole (Zentel) while the second prescribed mebendazole (Vermox). But these medications did not help as vomiting continued. This prompted them to seek medical help at SPCH, Benin City.

Physical examination revealed a socially withdrawn child with apathy. Oral hygiene was poor with long finger and toe nails. The hair was unkempt and his clothes were dirty. Anthropometry showed weight of $14.5 \mathrm{~kg}$, height of $100 \mathrm{~cm}$, and mid-upper-arm circumference of $13 \mathrm{~cm}$. Packed cell volume was $28 \%$. From the history and physical examination, we concluded that this was an emotionally deprived child with some evidence of child neglect. When B.M.'s step-mother was told that the child's symptoms and behaviour were related to the marital discord in the household, separation and maternal deprivation and that the child needs love, she said she has no time to pet B.M. and that he was merely wicked. The child's father was invited and the problem explained to him. He promised to reconcile with B.M.'s mother and bring her back into the household especially since his second wife has not been able to achieve pregnancy despite unprotected sexual intercourse for 3 years. B.M.'s mother has since re-united with her husband. They are all currently living in harmony, in the same household. At the time of this report, B.M. looks bright, cheerful, writes and participates in class activity. He no longer vomits. His appetite is good and his weight has risen to $15.8 \mathrm{~kg}$. His personal hygiene has improved considerably.

\section{Discussion}

This case is reported because it illustrates some aspects of the impact of intimate partner violence, marital discord, separation and maternal deprivation on the mental health of a child. It also serves to remind physicians of the need to consider emotional problems when evaluating a child presenting with unexplained persistent vomiting, apathy, social withdrawal behavioural problems and even malnutrition.

A child's relationship with the mother is by far the most important relationship a child could ever have in the first five years of life ${ }^{13}$. Maternal deprivation at this stage of life without a suitable mother substitute may spell a disaster in social and emotional development for the child. In the index case, the child was forcefully taken back to his father and abandoned by his mother. This child was closely attached to his mother before the temporary separation. Under-fives, because they are still immature in mind and body may not be able to cope with disturbances of inner life resulting from separation from their parents, particularly their mother. Absence of a suitable mother substitute as exemplified by the attitude of B.M.'s step-mother who claimed she has no time to pet B.M. because she believes that B.M. was merely 
wicked amounted to social and emotional deprivation. Thus, B.M.'s unfavourable experience during the period of separation from his mother further disturbed him since his step-mother who should have played the role of a mother substitute was insensitive and unresponsive to his predicament. This chain of events probably resulted in adjustment disorder with disturbance of emotion and conduct which manifested as apathy, social withdrawal and poor appetite in this patient. The antisocial behaviour of vomiting into his food was probably an attention-seeking strategy. Unhappiness portends danger for a child's personal and social adjustments. There are three essentials of happiness namely: acceptance, affection and achievement and are referred to as the "three $\mathrm{As}^{14}$." All three must be present for happiness to blossom ${ }^{14}$. It is also known that in social development, negativism begins in the second year and reaches its peak between the age of 3-6 years ${ }^{13}$. B.M.'s predicament started from the age of two years and lasted till age of five years. At present medical help is not commonly sought in cases of anti-social behaviour or aggressive behaviour simply because a layman does not consider these as paediatric medical problems. Even if children with psychiatric disorders are brought to the doctor, only a few will receive the services of a trained child psychiatrist.

One lesson to be learnt, as doctors, from this case is that a child presenting with vomiting, poor appetite, social withdrawal and apathy should be also be evaluated for emotional disorders. This child was evaluated for vomiting on two different occasions by two different doctors, a Non-specialist General Medical Practitioner and a month later, by a Consultant Paediatrician, both of whom made a diagnosis of "Helminthiasis" and prescribed antihelminthics which did not help. It is, therefore necessary in the future planning, to lay more emphasis on child psychiatry as a discipline because childhood psychiatric problems are likely to increase in number as our society becomes more sophisticated. A short-term solution is to ensure that Paediatric Residents Doctors spend only a few months in child psychiatric unit during their training.

The poor oral hygiene, over-grown finger and toe nails, unkempt hair and dirty clothes are subtle evidences of child neglect ${ }^{14}$ but at the same time could also be due to uncooperativeness of the child as in fact the parents appeared quite caring and concerned.

The parental reconciliation and subsequent return of B.M.'s mother into the household restored a normal social environment for the child, leading to increase in weight from $14.5 \mathrm{~kg}$ to $15.8 \mathrm{~kg}$ at the time of writing this report. This is in keeping with the long recognized fact that the most successful treatment of growth failure and weight loss due to psychosocial deprivation is restoration of a normal social environment ${ }^{15}$.

\section{References}

1. WHO Global Consultation on Violence and Health. Violence: a public health priority. Geneva, World Health Organisation, 1996 (document WHO/EHA/ SPI. POA. 2).

2. Krug EG, Dahlberg LL, Mercy JA, Zwi AB, Lozano R. World Report on Violence and Health. WHO, Geneva, 2002: 89 - 121.

3. Rodgers K. Wife assault: the finding of a national survey. Juristat Service Bulletin. 1994; 14: 1 - 22.

4. O'Conner M. Making the links: towards an integrated strategy for elimination of violence against women in intimate relationship with men. Dublin Women's Aid, 1995.

5. Granados SM. Reproductive health and violence against women: a gender perspective. J Nuevo Leon Association Mexicana de Poblacion, Consejo Estatal de Poblacion, 1996.

6. Augustyn M, Zuckerman B. Impact of violence on children. In: Kliegman RM, Behrman RE, Jenson HB, Stanton BF (eds). Nelson Textbook of Pediatrics $18^{\text {th }}$ edn. Philadelphia, Saunder Elsevier, 2007: 166-171.

7. Heise LI, Ellsberg M, Gottemoeller M. Ending violence against women. Baltimore, MD, Johns Hopkins University School of Public Health, Center for Communication Programs, 1999 (Population Report Series 1, No 11).

8. McClockey LA, Figueredo AJ, Koss MP. The effects of family violence on children's mental health. Child Development 1995;66:1239 -1241.

9. Edleson JL. Children's witnessing of adult domestic violence. J Interpers Violence 1999;14:839-850.

10. Houriles EN, Murphy CM, O'Leary KD. Interspousal aggression, marital discord and child problems. Consul and Clin Psycho 1989;57:453-455.

11. Wallerstein JS. Separation, divorce and remarriage. In: Levine MD, Caney WB, Crocher AC (eds). Developmental Behavioural Paediatrics $2^{\text {nd }}$ edn. Philadelphia, WB Saunder Company 1992:136-146. 
12. Serwint JR. Separation, loss and bereavement. In: Kliegman RM, Behrman RE, Jenson HB, Stanton BF (eds). Nelson Textbook of Pediatrics. $18^{\text {th }}$ edn. Philadelphia, Saunder Elsevier, 2007:86-91.

13. Banga AK, Banga $U$ (eds). Child Development and Developmental Diagnosis. New Delhi, Japee Brothers Medical Publishers, 1999:3-33.

14. Sirotrak AP, Krugman RD. Child abuse and neglect. In: Hay WW Jnr, Levin MJ, Sondheimer
JM, Deterding RR (eds). Current Diagnosis and Treatment in Pediatrics. $18^{\text {th }}$ edn. New York, McGraw Hill Companies, 2007:219-244.

15. Skuse D, Gilmour J. Psychological disorders associated with short stature. In: Kelnar CJH, Savage MO, Stirling HF, Saenger P. (eds) Growth Disorders: Pathophysiology and Treatment. London, 1998:483-495.

\section{How to cite this article?}

Onyiriuka AN. Impact of Interspousal Violence and Maternal Deprivation on a Child's Mental and Physical Health: A Case Report. J Nep Paedtr Soc 2011;31(2):137-140. 